\title{
Preparation of Carbamide Containing Biocomposite Fertilizer with the Increase Water Resistance Based on the Aspen Bark
}

\author{
Evgeniya V. Veprikova, Irina V. Korolkova, \\ Nikolai V. Chesnokov and Boris N. Kuznetsov* \\ Institute of Chemistry and Chemical Technology SB RAS \\ Federal Research Center "Krasnoyarsk Science Center SB RAS" \\ 50/24 Akademgorodok, Krasnoyarsk, 660036, Russia
}

Received 27.11.2017, received in revised form 30.11.2017, accepted 02.12.2017

The method of preparation of carbamide containing biocomposite fertilizer with the increase water resistance, including the impregnation of a support from aspen bark by urea water solution and the subsequent deposition of the urea nitrate, was proposed. The influence of conditions of a biocomposite fertilizer obtaining on its resistance to nitrogen leaching by water was studied. It was shown that the urea transformation to nitrate form on a support surface allow to decrease by approximately 2 times the nitrogen leaching from the biocomposite fertilizer.

Keywords: aspen bark, urea, biocomposite fertilizer, preparation, leaching of nitrogen, resistance.

DOI: $10.17516 / 1998-2836-0044$.

(C) Siberian Federal University. All rights reserved

* Corresponding author E-mail address: veprikova2@mail.ru 


\title{
Получение карбамидсодержащего \\ биокомпозитного удобрения \\ с повышенной водостойкостью
}

на основе коры осины

\author{
Е.В. Веприкова, И.В. Королькова, \\ Н.В. Чесноков, Б.Н. Кузнецов \\ Институт химии и химической технологии СО РАН \\ ФИЦ «Красноярский научный иентр СО РАН» \\ Россия, 660036, Красноярск, Академгородок, 50/24
}

Предложен способ получения карбамидсодержащего биокомпозитного удобрения с повыщенной водостойкостью, включающий пропитку подложки из коры осины водным раствором мочевины и последующее осаждение нитрата мочевины. Изучено влияние условий получения биокомпозитного удобрения на его устойчивость к вымыванию азота водой. Показано, что превращение мочевины на поверхности подложки в нитратную форму позволяет уменьшить вымывание азота из биокомпозитного удобрения в среднем в 2 раза.

Ключевые слова: кора осины, мочевина, биокомпозитное удобрение, получение, вымывание азота, устойчивость.

\section{Введение}

Осина относится к наиболее распространенным лиственным породам деревьев на территории России. Площадь, занимаемая этой породой, увеличивается естественным образом, поскольку после рубки хвойных пород лесосеки возобновляются корнеотпрысковой осиной. Вследствие криволинейности ствола, низкой механической плотности и склонности к гниению более 30 \% срубленной древесины осина бракуется на лесосеке. Часть древесных отходов утилизируется сжиганием. Но основная масса вывозится в отвалы или остается на местах заготовки, загрязняя окружающую среду продуктами гниения и создавая повышенную пожароопасность.

Многочисленные исследования показывают огромный потенциал коры осины как сырья для получения различных материалов с востребованными свойствами $[1,2]$. Важным направлением утилизации коры осины является ее химическая переработка с получением биологически активных веществ [3-7]. Кору осины и остатки после ее экстрагирования возможно применять в качестве эффективных кормовых добавок $[4,8,9]$. В работе [10] показана возможность применения коры осины в качестве наполнителя полимерных композитов.

Целлюлозосодержащие материалы, в частности и отходы древесной коры, являются дешевым и доступным сырьем для получения сорбентов и пористых носителей, на основе которых могут быть созданы композитные материалы с различными свойствами. Большой интерес представляют карбамидсодержащие сорбенты на основе различных отходов биомассы (дре-

$$
-503-
$$


весные опилки, льнотреста и др.), способные эффективно поглощать формальдегид и аммиак при очистке вентиляционных выбросов ряда производств. Такие материалы характеризуются высокой сорбционной активностью в отношении ряда металлов (цинка, железа, хрома, кадмия и др.), что определяет их потенциал и в процессах очистки сточных вод [11, 12]. В литературе описаны азотсодержащие материалы на основе березовой коры и древесины различных пород, которые возможно использовать в качестве органических удобрений пролонгированного действия $[13,14]$. Следует отметить, что эффективность применения карбамидсодержащих материалов, особенно в условиях контакта с водными средами, зависит от их устойчивости к вымыванию мочевины водой. Одним из способов повышения водостойкости является перевод активного компонента в малорастворимую форму. Такие способы традиционно используются в практике получения нанесенных катализаторов. Как известно, на перевод вещества в менее растворимое соединение большое влияние оказывают физико-химические свойства применяемого пористого носителя [15]. Поэтому разработка способа получения композита с заданными свойствами на вновь предлагаемом пористом носителе является актуальной задачей.

Цель работы состояла в изучении влияния условий получения карбамидсодержащего биокомпозитного удобрения на основе подложки из коры осины на его водостойкость.

\section{Экспериментальная часть}

Исходным сырьем для получения пористой подложки биокомпозитного удобрения (БУ) служила кора осины (Рopuus tremula L.), заготовленная в окрестностях г. Красноярска. Кору высушивали до воздушно-сухого состояния при комнатных условиях, измельчали на дезинтеграторе марки "Nossen" (Германия) и готовили смесь следующего фракционного состава, мас. \%: $(0.5-1.0)$ мм - 75; $(1,0-2,0)$ мм - 25. Массовое соотношение корки и луба в сырье составляло 60,6 и 39,4 мас. \% соответственно.

Кору осины обрабатывали 1\%-м водным раствором $\mathrm{NaOH}$ аналогично методике, описанной в работе [16]. Значение гидромодуля на стадии щелочной обработки было равно 15 , на остальных стадиях - 10. Получаемую из коры пористую подложку сушили до воздушносухого состояния при $50^{\circ} \mathrm{C}$.

Получение БУ включало приготовление карбамидсодержащей подложки и осаждение на ее поверхности нитрата мочевины. Нанесение мочевины проводили пропиткой пористой подложки водными раствором мочевины марки ч.д.а. различной концентрации, г/л: 6,25, 31,25, $62,50,93,25,125,00,156,25$. Количество раствора мочевины, применяемого для пропитки, соответствовало влагоемкости подложки, которую определяли по ГОСТ 24160-80. В результате пропитки получали образцы подложек, содержащих от 1 до 25 мас. \% мочевины.

Стадии процесса получения биокомпозитного удобрения и их условия приведены в табл. 1.

Перед пропиткой раствором кислоты образцы карбамидсодержащих подложек выдерживали на водно-ледяной бане в течение 30 мин, затем при перемешивании образца добавляли пропиточный раствор и выдерживали еще 20-30 мин.

Вымывание мочевины и нитрата мочевины из получаемых карбамидсодержащих подложек и биокомпозитных удобрений проводили в стационарном режиме при комнатных условиях по аналогии с методикой работы [13]. К исследуемому образцу массой 4 г приливали 1 дм 
Таблица 1. Основные стадии получения биокомпозитного удобрения (БУ) на основе подложки из коры осины

Table 1. The main stages of preparation of biocomposite fertilizer (BF) based on support from aspen bark

\begin{tabular}{|c|c|}
\hline Стадия & Условия получения \\
\hline Пропитка & $\begin{array}{l}\text { Водные растворы, содержащие } 6,25,31,25,62,50,93,25,125,00, \\
156,25 \text { г/л мочевины. Объем пропиточного раствора мочевины } 1,6 \\
\text { см }^{3} \text { на } 1 \text { г подложки }\end{array}$ \\
\hline $\begin{array}{l}\text { Изотермическая выдержка } \\
\text { карбамидсодержащей подложки }\end{array}$ & $\begin{array}{l}\text { Выдержка пропитанного образца в закрытой посуде. Время } \\
\text { выдержки от } 0,5 \text { до } 24 \text { ч; температура }(21 \pm 1){ }^{\circ} \mathrm{C}\end{array}$ \\
\hline $\begin{array}{l}\text { Сушка карбамидсодержащей } \\
\text { подложки }\end{array}$ & $\begin{array}{l}\text { Температура }(100 \pm 5)^{\circ} \mathrm{C} . \text { Высушивание до воздушно-сухого } \\
\text { состояния }\end{array}$ \\
\hline $\begin{array}{l}\text { Пропитка карбамидсодержащей } \\
\text { подложки раствором азотной } \\
\text { кислоты }\end{array}$ & $\begin{array}{l}\text { Мольное соотношение мочевины в подложке и азотной кислоты } \\
\text { от 1:0,5 до 1:2,0. Плотность азотной кислоты } 1,4 \text { г/см }{ }^{3} \text {. Объем } \\
\text { пропиточного раствора кислоты } 1,6 \mathrm{~cm}^{3} \text { на } 1 \text { г подложки. Пропитка } \\
\text { при температуре } 0 . .+2{ }^{\circ} \mathrm{C}\end{array}$ \\
\hline Выдержка образца & $\begin{array}{l}\text { Выдержка пропитанного образца в эксикаторе } 24 \text { ч при } \\
\text { температуре }(21 \pm 1){ }^{\circ} \mathrm{C} \text {; осушитель - хлорид кальция }\end{array}$ \\
\hline Сушка БУ & $\begin{array}{l}\text { Температура }(45 \pm 5)^{\circ} \mathrm{C} . \text { Высушивание до воздушно-сухого } \\
\text { состояния }\end{array}$ \\
\hline
\end{tabular}

дистиллированной воды и выдерживали в течение 24 ч. Затем количественно отделяли образец от раствора. В водных растворах, содержащих мочевину, азот определяли фотометрическим методом по содержанию биурета в соответствии с ГОСТ 32555-2013. В растворах, содержащих нитрат мочевины, определяли общий азот по методу Кьельдаля (ГОСТ 32467-2013).

Вымывание азота водой из исследуемых образцов $\left(\mathrm{B}_{\mathrm{N}}, \%\right)$ определяли следующим обра30м:

$$
\mathrm{B}_{\mathrm{N}}=\left[\mathrm{m}_{\mathrm{N}}^{2}: \mathrm{m}_{\mathrm{N}}^{1}\right]_{*} 100,
$$

где $\mathrm{m}_{\mathrm{N}}{ }^{1}-$ исходное количество азота в подложке или БУ, г; $\mathrm{m}_{\mathrm{N}}{ }^{2}-$ количество азота, перешедшего в раствор, г.

По изменению массы образца карбамидсодержащей подложки в процессе вымывания водой определяли количество водорастворимых веществ (ВРВ, \%), перешедших в раствор:

$$
\mathrm{BPB}=\mathrm{m}_{1}-\mathrm{m}_{2}-\mathrm{m}_{\mathrm{m}}{ }^{2},
$$

где $\mathrm{m}_{1}$ - абсолютно сухая масса образца подложки, отобранная для вымывания, г; $\mathrm{m}_{2}$ - абсолютно сухая масса остатка образца подложки, г; $\mathrm{m}_{\mathrm{m}}{ }^{2}$ - количество мочевины, перешедшей в раствор с исследуемого образца, г (пересчитывается на основании количества азота в растворе).

Отдельно получали образцы нитрата мочевины по аналогии с методикой, приведенной в работе [17]. Для растворения мочевины применяли дистиллированную воду и растворы после вымывания азота из карбамидмодержащих подложек (образцы содержали 10 и 25 мас. \% мочевины и получены в условиях 24-часовой изотермической выдержки после пропитки подложки, табл. 1). Осаждение нитрата мочевины проводили при температуре $0 . .+2{ }^{\circ}$ С. Отфильтрованный осадок выдерживали в эксикаторе над осушителем в течение 24 ч, затем сушили до воздушно-

$$
-505-
$$


сухого состояния при $(45 \pm 5)^{\circ} \mathrm{C}$. Выход и растворимость получаемого нитрата мочевины определяли по методу работы [18].

ИК-спектры подложки из коры осины до и после нанесения мочевины были получены на ИК-Фурье спектрометре Tensor-27 (Bruker, Германия) в области 4000-400 см-1. Образцы для получения ИК-спектров готовили в виде таблеток в матрице бромистого калия при одинаковых условиях (5 мг на 1000 мг бромида калия). Полученная спектральная информация была обработана с помощью пакета программ OPUS (версия 5.5).

Электронно-микроскопические исследования образцов подложки из коры осины, содержащих мочевину, проводили на электронных растровых микроскопах ТМ - 1000 TM - 3000 (НITACHI, Япония).

\section{Результаты и обсуждение}

Получение карбамидсодержащего биокомпозитного удобрения осуществлено пропиткой пористой подложки из коры осины водным раствором мочевины. При этом пропитку коры заданным количеством мочевины предложено проводить, исходя из влагоемкости подложки. В этом случае объем пропиточного раствора практически равен объему пор подложки, что дает возможность наносить точно рассчитанное количество активного компонента. Это позволяет точно определить количество азотной кислоты, необходимой для последующей обработки пропитанной подложки для осаждения на ее поверхности нитрата мочевины (табл. 1). Трансформация мочевины в соединение, характеризующееся малой растворимостью в воде, необходима для повышения водостойкости получаемого биокомпозитного удобрения.

\section{Получение карбамидсодержащих подложек из коры осины}

Из образцов подложки с нанесенной мочевиной водой удаляется большое количество последней, о чем свидетельствуют данные по вымыванию азота. В минимальных количествах (в среднем 67,7 \%) азот удаляется водой из образцов подложек, содержащих от 1 до 10 мас. \% мочевины (рис. 1).

Повышение количества мочевины в подложке до 25 мас. \% сопровождается уменьшением ее устойчивости к вымыванию азота.

Важным фактором формирования водостойкости получаемых карбамидсодержащих подложек является продолжительность их изотермической выдержки перед сушкой. Рис. $2 a$ показывает, что увеличение времени выдержки приводит к повышению вымывания азота независимо от содержания мочевины в подложках. В большей степени продолжительность выдержки влияет на свойства подложки, содержащей 25 мас. \% мочевины. Так, изотермическая выдержка такого образца в течение 12 ч перед сушкой приводит к практически полному вымыванию нанесенного вещества. Увеличение продолжительности выдержки до 24 ч не влияет на его водостойкость. Видно, что для получения карбамидсодержащех подложек с минимальным вымыванием азота достаточно выдерживать их при заданных условиях перед сушкой в течение 0,5 ч независимо от количества нанесенной мочевины (рис. $2 a$ ).

Повышение времени изотермической выдержки более 4 ч приводит и к увеличению количеств ВРВ, вымываемых водой из подложек одновременно с мочевиной (рис. 2б). Причем с ростом содержания мочевины в подложках количество таких веществ существенно увеличи-

$$
-506-
$$




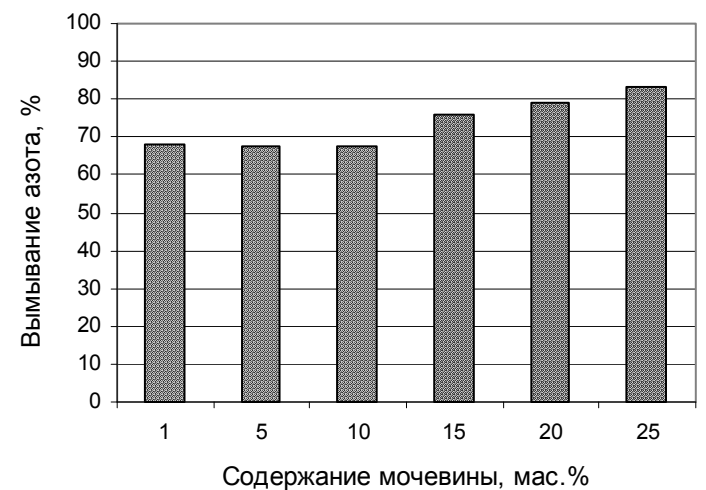

Рис. 1. Влияние содержания мочевины в подложке из коры осины на вымывание азота водой (время изотермической выдержки перед сушкой 0,5 ч)

Fig. 1. The influence of urea content in support from aspen bark on the nitrogen leaching by water (isothermal exposure time before drying $0,5 \mathrm{~h}$ )

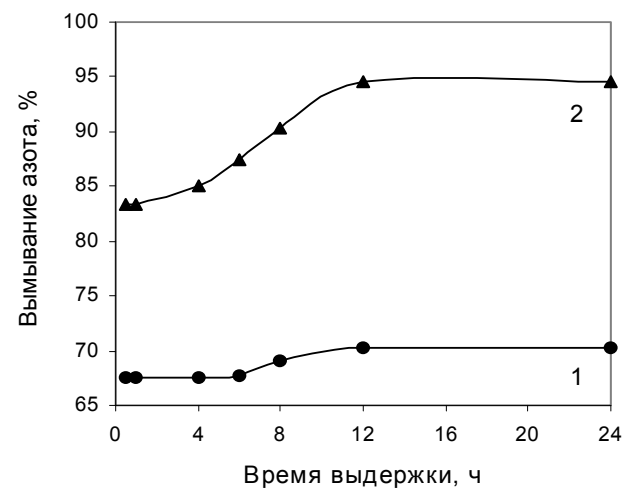

a

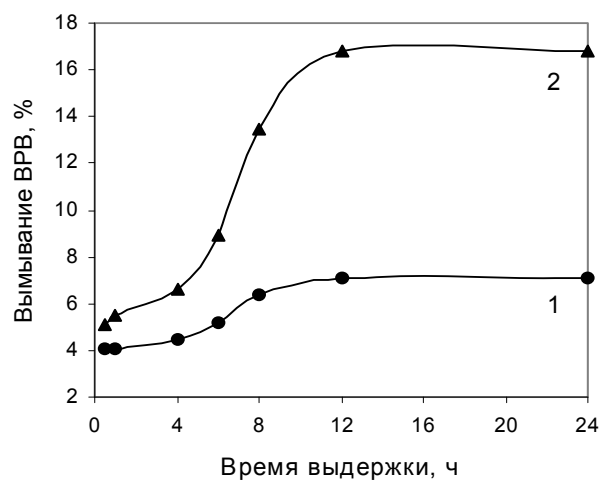

б

Рис. 2. Влияние времени изотермической выдержки карбамидсодержащей подложки из коры осины на вымывание водой азота (а) и водорастворимых веществ ВРВ (б): 1 - подложка содержит 10 мас. \% мочевины; 2 - подложка содержит 25 мас. \% мочевины

Fig. 2. The influence of isothermal exposure time of carbamide containing support from aspen bark on the leaching by water of nitrogen (a) and water soluble substances WSS (b): 1 - support contains 10 mass \% of urea; 2 - support contains 25 mass \% of urea

вается. Из образцов, содержащих 10 и 25 мас. \% мочевины и получаемых с 12- или 24-часовой выдержкой, вымывается в 1,9 и 4,4 раза больше водорастворимых веществ по сравнению с исходной пористой подложкой. Отметим, что содержание таких веществ в подложке из коры осины составляет $3,8 \%$.

Сравнение результатов по вымыванию азота и водорастворимых веществ из карбамидсодержащих подложек, получаемых при различных значениях изотермической выдержки, показывает взаимосвязь этих свойств (рис. $2 a$ и б). Можно предположить, что образование повышенного количества водорастворимых веществ препятствует закреплению мочевины в подложке. 


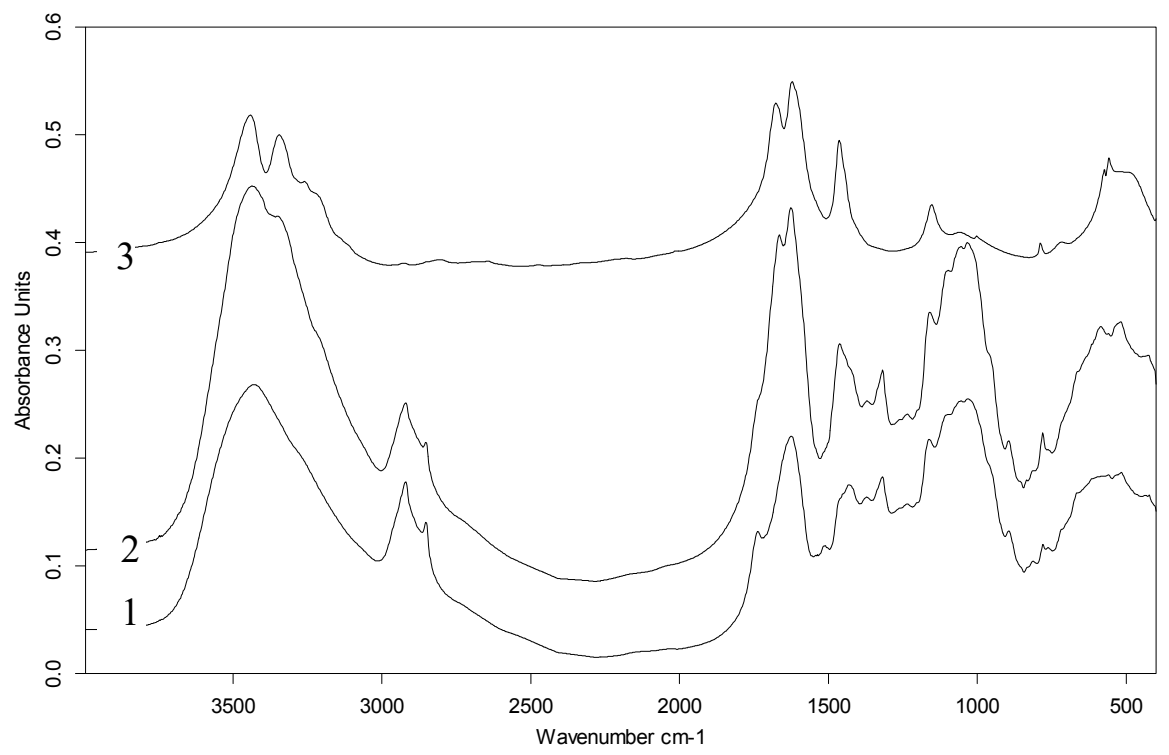

Рис. 3. ИК-спектры подложки из коры осины до (1) и после (2) нанесения мочевины: 3 - ИК-спектр мочевины

Fig. 3. IR-spectra of support from aspen bark before (1) and after (2) deposition of urea and IR spectrum of urea (3)

На рис. 3 приведены ИК-спектры подложки из коры осины до (кривая 1) и после пропитки раствором мочевины (кривая 2). После пропитки образец содержал 10 мас. \% мочевины (изотермическая выдержка - 24 ч). На кривой 3 приведен спектр мочевины. Сравнение полученных спектров показывает, что пропитка подложки раствором мочевины приводит к появлению в спектре образца (кривая 2) новых полос поглощения, обусловленных колебаниями отдельных структурных элементов мочевины [19]. Отсутствие сдвига характеристических полос поглощения как мочевины, так и подложки может свидетельствовать о физической сорбции мочевины пористой подложкой из коры осины.

Этот факт - позитивный момент для получения биокомпозитного удобрения, поскольку нанесенная на подложку мочевина является предшественником целевого соединения - нитрата мочевины. Очевидно, что химическое взаимодействие нанесенного вещества с подложкой из коры осины способно затруднить его преобразование в нитратную форму при последующей кислотной обработке.

Сравнение результатов по вымыванию водорастворимых веществ и данных ИКспектроскопии позволяет предположить, что за счет пропитки подложки растворами мочевины в сочетании с продолжительной изотермической выдержкой происходит увеличение растворимости органических веществ подложки в воде без изменения их химической природы (рис. 26 и 3 ).

Было установлено, что высушивание пропитанной раствором мочевины подложки целесообразно проводить при температуре $(100 \pm 5){ }^{\circ} \mathrm{C}$. Максимальное значение этого параметра ограничено значением температуры плавления мочевины $\left(132,7^{\circ} \mathrm{C}\right)$, выше которой начинается ее разложение [20]. Уменьшение температуры высушивания сопровождается увеличением 
вымывания мочевины, и при $40{ }^{\circ} \mathrm{C}$ из получаемых образцов карбамидсодержащих подложек водой удаляется от 80,3 до 92,5 \% нанесенного вещества.

\section{Изучение влияния условий получения биокомпозитного удобрения, содержащего нитрат мочевины, на его водостойкость}

Было установлено влияние времени изотермической выдержки карбамидсодержащих подложек из коры осины на водостойкость биокомпозитных удобрений, полученных в результате перевода мочевины в нитратную форму (табл. 2). Образцы удобрений, представленные в табл. 2, были получены пропиткой карбамидсодержащих подложек растворами азотной кислоты при мольном соотношении мочевины и кислоты, равном 1:1.

Полученные результаты показывают, что существенное уменьшение вымывания азота за счет перевода мочевины в нитратную форму достигнуто только для образцов БУ, полученных на основе карбамидсодержащих подложек с минимальным временем изотермической выдержки (табл. 2). Низкая устойчивость к вымыванию азота образцов БУ, полученных после 24-часовой выдержки, может быть обусловлена большим содержанием водорастворимых веществ в пропитанных мочевиной подложках.

Были проведены эксперименты по осаждению нитрата мочевины из насыщенного раствора последней, для приготовления которых использовали дистиллированную воду и водные растворы, полученные в результате вымывания карбамидсодержащих подложек. Эти растворы, помимо мочевины, содержали водорастворимые вещества, входящие в состав подложки из коры осины. Данные табл. 3 показывают, что растворимость нитрата мочевины, осажденного из растворов, содержащих эти вещества, существенно увеличивается, а его выход (от теоретического значения) уменьшается.

Можно предположить, что наблюдаемое негативное влияние водорастворимых веществ коры осины на выход и растворимость нитрата мочевины может обуславливать большое вымывание азота из образцов биокомпозитных удобрений, получаемых при продолжительной изотермической выдержке пропитанных подложек перед сушкой (табл. 2 и 3).

Представленные в табл. 4 результаты показывают, что биокомпозитные удобрения на основе подложек, содержащих 1 и 5 мас. \% мочевины, по вымыванию азота водой существенно превосходят образцы удобрений на основе подложек с $\geq 10$ мас. \% мочевины. Для таких образ-

Таблица 2. Вымывание азота из биокомпозитных удобрений (БУ) в зависимости от содержания мочевины в пористой подложке и времени ее изотермической выдержки

Table 2. The nitrogen leaching from biocomposite fertilizers (BF) depending on the urea content in porous support and on the time of its isothermal exposure

\begin{tabular}{|c|c|c|c|}
\hline $\begin{array}{c}\text { Содержание мочевины } \\
\text { в подложке, мас. \% }\end{array}$ & $\begin{array}{c}\text { Время изотермической } \\
\text { выдержки подложки, ч }\end{array}$ & $\begin{array}{c}\text { Вымывание азота } \\
\text { из подложки, \% }\end{array}$ & $\begin{array}{c}\text { Вымывание азота } \\
\text { из БУ, \%* }\end{array}$ \\
\hline \multirow{2}{*}{10} & 0,5 & 67,5 & 38,2 \\
& 24 & 70,3 & 69,9 \\
\hline \multirow{2}{*}{25} & 0,5 & 83,4 & 36,4 \\
& 24 & 94,5 & 95,2 \\
\hline
\end{tabular}

*- общий азот.

$$
-509-
$$


цов БУ максимальное уменьшение вымывания азота было достигнуто при мольном отношении мочевины и кислоты на стадии кислотной пропитки, равном 1:1,5. Когда на подложку нанесено $\geq 10$ мас. \% мочевины, оптимальное соотношение компонентов составляет 1:1.

Применение избытка кислоты для пропитки подложек с различным содержанием мочевины приводит к увеличению вымывания азота (табл. 4). Это может быть вызвано повышением растворимости нитрата мочевины в избытке азотной кислоты [20].

Данные табл. 4 показывают, что варьирование количества азотной кислоты на стадии пропитки подложки из коры осины, содержащей 10 мас. \% и более мочевины, позволяет регулировать устойчивость получаемых БУ к вымыванию азота водой в достаточно широком интервале. Минимальное значение показателя вымывания для БУ сравнимо с вымыванием азота из нитрата мочевины, осажденного из воды (табл. 3 и 4).

Было установлено, что подложки, содержащие 1 и 5 мас. \% мочевины, характеризуются неравномерностью и низкой плотностью распределения ее кристаллов по поверхности (рис. 4).

Очевидно, за счет такого распределения мочевины только часть кислоты, используемой для пропитки подложек, взаимодействует с ней и образует малорастворимый нитрат. В ре-

Таблица 3. Выход и растворимость нитрата мочевины, полученного из различных растворов

Table 3. Yield and solubility of urea nitrate obtained from different solutions

\begin{tabular}{|l|c|c|c|}
\hline \multicolumn{1}{|c|}{ Раствор } & $\begin{array}{c}\text { Содержание ВРВ* в } \\
\text { растворах, г/л }\end{array}$ & $\begin{array}{c}\text { Выход нитрата } \\
\text { мочевины, \% }\end{array}$ & $\begin{array}{c}\text { Растворимость } \\
\text { нитрата мочевины, \% }\end{array}$ \\
\hline Дистиллированная вода & нет & 91,8 & 34,2 \\
\hline $\begin{array}{l}\text { Водный раствор из подложки, } \\
\text { содержащей 10 мас. \% мочевины }\end{array}$ & 0,28 & 79,8 & 70,2 \\
\hline $\begin{array}{l}\text { Водный раствор из подложки, } \\
\text { содержащей 25 мас. \% мочевины }\end{array}$ & 0,67 & 57,2 & 96,4 \\
\hline
\end{tabular}

* ВРВ - водорастворимые вещества подложки из коры осины.

Таблица 4. Влияние количества азотной кислоты, используемой для пропитки подложек из коры осины, на вымывание азота из биокомпозитных удобрений (БУ) (изотермическая выдержка 0,5 ч)

Table 4. The influence of the amount of nitric acid using for impregnation of aspen bark supportson the nitrogen leaching from biocomposite fertilizers (BF) (isothermal exposure $0.5 \mathrm{~h}$ )

\begin{tabular}{|c|c|c|c|c|}
\hline \multirow{2}{*}{$\begin{array}{c}\text { Молярное } \\
\text { отношение } \\
\text { мочевины к } \\
\text { кислоте }\end{array}$} & \multicolumn{4}{|c|}{ Вымывание азота из БУ, \%* } \\
\cline { 2 - 5 } & 1 & 5 & 10 & 25 \\
\hline $1: 0,2$ & 67,7 & 67,6 & 66,9 & 82,8 \\
$1: 0,5$ & 65,2 & 64,3 & 52,4 & 61,6 \\
$1: 0,7$ & 60,5 & 57,7 & 44,7 & 39,7 \\
$1: 1,0$ & 58,4 & 54,6 & 38,2 & 38,4 \\
$1: 1,5$ & 57,9 & 52,2 & 40,1 & 48,8 \\
$1: 2,0$ & 69,8 & 68,1 & 48,4 & \multicolumn{3}{|c|}{ Количество мочевины в подложке, мас. \% } \\
\hline
\end{tabular}

*- общий азот. 

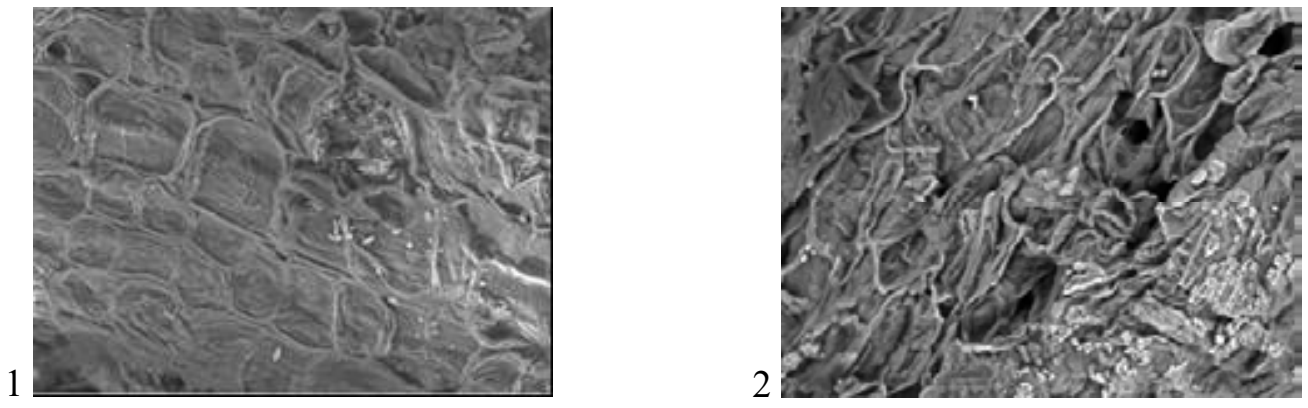

Рис. 4. РЭМ изображения поверхности подложек из коры осины, содержащих 1 мас. \% (1) и 5 мас. \% (2) мочевины. Увеличение в 1000 раз

Fig. 4. SEM images of surface of supports from aspen bark containing 1 mass \% (1) and 5 mass \% (2) of urea. A magnification of 1000 times

Таблица 5. Влияние температуры сушки биокомпозитного удобрения (БУ) на вымывание азота водой (содержание мочевины в подложке 25 мас. \%; 0,5 ч - изотермическая выдержка; мольное отношение мочевины к кислоте 1:1)

Table 5. The influence of temperature of biocomposite fertilizer (BF) drying on nitrogen leaching by water (urea content in support 25 mass \%; isothermal exposure $0,5 \mathrm{~h}$; urea to acid molar ratio $1: 1$ )

\begin{tabular}{|c|c|c|}
\hline Температура сушки, ${ }^{\circ} \mathrm{C}$ & Дополнительная обработка & Вымывание азота, \%** \\
\hline 50 & Выдержка над осушителем* & 36,4 \\
50 & Без выдержки & 42,5 \\
100 & Выдержка над осушителем* & 38,2 \\
100 & Без выдержки & 54,3 \\
\hline
\end{tabular}

*Условия согласно табл. 1, ** общий азот.

зультате получаемые на основе таких подложек биокомпозитные удобрения характеризуются наименьшей водостойкостью.

Выдержка карбамидсодержащих подложек после пропитки раствором азотной кислоты в эксикаторе в присутствии осушителя (хлорида кальция) позволяет удалить избыток влаги с поверхности получаемых образцов. Этот прием оказывает позитивное влияние на устойчивость биокомпозитных удобрений к вымыванию азота водой независимо от температуры их высушивания (табл. 5). Очевидно, избыток влаги в сочетании с повышенной температурой может приводить к увеличению растворимости нитрата мочевины при нагревании частиц удобрения до температуры сушки.

Вероятно, за счет такого изменения растворимости образец БУ, высушенный сразу после получения при $100{ }^{\circ} \mathrm{C}$, характеризуется наибольшим вымыванием азота. При условии применения выдержки над осушителем повышение температуры сушки от 50 до $100{ }^{\circ} \mathrm{C}$ мало влияет на водостойкость получаемых удобрений (табл. 5).

\section{Заключение}

Показана возможность получения карбамидсодержащего биокомпозитного удобрения с повышенной устойчивостью к вымыванию азота водой методом пропитки подложки из коры 
осины водным раствором мочевины и последующим осаждением на ее поверхности малорастворимого нитрата мочевины.

Выявлено влияние количества мочевины, нанесённой на подложку из коры осины, и продолжительности изотермической выдержки пропитанной подложки перед сушкой на водостойкость биокомпозитного удобрения.

Определены условия, позволяющие получать карбамидсодержащие биокомпозитные удобрения с минимальным вымыванием азота: количество мочевины, нанесенной на подложку, составляет от 10 до 25 мас. \%; продолжительность изотермической выдержки пропитанной подложки перед сушкой - 30 мин; пропитка азотной кислотой при мольном соотношении мочевины в подложке и кислоты, равном 1:1. Вымывание азота из получаемых в этих условиях удобрений в течение суток не превышает 38,2 \%, что обуславливает эффект их пролонгированного действия.

Показана возможность варьирования количества азота, вымываемого водой в течение суток из биокомпозитных удобрений, от 82,8 до 36,4 \% за счет изменения количества азотной кислоты в процессе осаждения нитрата мочевины. Это позволяет получать удобрения с различным периодом активного действия.

\section{В работе использованы приборы Красноярского регионального Центра коллективного} пользования ФИЦ КНЦ СО РАН.

\section{Список литературы}

1. Кузнецов Б.Н., Левданский В.А., Кузнецова С.А. Химически продукты из древесной коры: монография. Красноярск: Сиб. фед. ун-т, 2012. 260 с. [Kuznetsov B. N., Levdanskiy V.A., Kuznetsova S.A. Chemical products of woody-crust: monograph. Krasnoyarsk: Siberian Federal University, 2012. 260 p. (in Russ.)]

2. Дейнеко И.П., Фаустова Н.М. Элементный и групповой химический состав коры и древесины осины. Химия растительного сырья 2015. № 1. С. 51-62. [Deineko I.P., Faustova N.M. Element and group composition of aspen bark and wood. Chemistry of plant raw materials 2015. №1. P. 51-62 (in Russ.)]

3. Луцак И.В., Штриголь С.Ю. Психотропні властивості екстракту к4ори осики. Украінський биофармацевтичний журнал 2012. T. 18-19 (1-2). C. 50-55. [Lutsak I.V., Shtrygol S. Yu. Psychotropic properties of Aspen bark extract. Ukrainian Biopharmaceutical Journal 2012. Vol. 18-19 (1-2). P. 50-55. (in Ukrain.)]

4. Соболева С.В., Ченцов Л.И., Воронин В.М. Переработка коры осины с получением биологически активных веществ и кормовых продуктов. Красноярск: СибГТУ, 2013. 77 с. [Sobolev S.V., Chentsov L.I., Voronin V.M. Treatment of aspen bark with obtaining of biological active substances and feed products. Krasnoyarsk: Sub. FTU, 2013. 77 p. (in Russ.)]

5. Patent 2016296583 US. Desert Harvest. Methods and compounds for intensive skin repair and healing including active organic and synthetic compounds - Publ. date 13.10.2016.

6. Patent $106138378 \mathrm{CN}$. Yang Xiumei. Gua Xi San detoxifying and face-nourishing tablet. Publ. Date 23.11.2016.

7. Сафин Р.Г., Зиатдинова Л.Ф., Арсланова Г..Р. Экстрагирование биологически активных веществ из коры осины. Лесной вестник 2017. Т. 21(2). C. 65-69. [Safin R.G., Ziatdinova L.F., 
Arslanova G.R. Extraction of biological active substances from aspen bark. Forest Bulletin 2017. V. 21(2). P. 65-69 (in Russ.)]

8. Соболева С.В., Литовка Ю.А. Переработка послеэкстракционного остатка коры осины с получением кормовых продуктов. Химия растительного сырья 2011. №2. C. 83-86. [Sobolev S.V., Litovka Yu.A. The treatment of post-extraction residual of aspen bark with feed products obtaining. Chemistry of plant raw materials 2011. №2. P 83-86 (in Russ.)]

9. Patent 106417998 CN. Tang Tingting, Li Xin, Huang He. Feed additive capable of improving intestinal tracts of sea cucumbers and preparation method of feed additive. Publ. Date 22.02.2017.

10. Martin C.N. Vemele, Ahmed Koubaa, Alain Cloutier, Patrice Soulounganga Effect of fiber content and size on the mechanical properties of bark/HDPE composites. Composites: Part A 2010. Vol. 41. P. 131-137.

11. Жукова И.Л., Орехова С.Е., Хмылко Л.И. Сорбенты на основе целлюлозосодержащих материалов и их утилизация. Экология и промышленность России 2009. №6. С. 30-33. [Zhukova I.L., Orechova S.E., Khmilko L.I. Sorbent on the base of cellulose-contended materials and its utilization. Ecology and industry of Russia 2009. №6. P. 30-33. (in Russ.)]

12. Хохотва А.П. Адсорбция тяжелых металлов сорбентом на основе сосновой коры. $X u$ мия и технология воды 2010. Т. 32(6). С. 604-612. [Khokhotva O.P. Sorption of heavy metals on a sorbent based on pine bark. J. of Water Chemistry and technology 2010. T. 32(6). P. 604-612. (in Russ.)]

13. Sheikh Ali Ahmed, Jong In Kim, Kyung Mi Park, Su Kyoung Chun Ammonium nitrateimpregnated woodchips: a slow-release fertilizer for plants. J. Wood Science. 2011. Vol. 57. P. 295-301.

14. Кузнецова С.А., Кузнецов Б.Н., Скурыдина Е.С., Максимов Н.Г., Калачева Г.С., Ульянова О.А., Скворцова Г.П. Синтез и свойства биокомпозитных удобрений на основе мочевины и коры березы. Журнал Сибирского федерального университета. Химия 2013. Т. 6(4). С. 380 - 393. [Kuznetsova S.A., Kuznetsov B.N., Skurydina E.S., Maksimov H.G., Kalachova G.S., Ulyanova O.A., Skvortsova G.P. Synthesis and properties of biocomposite fertilizers on the basis of urea and birch bark. Journal of Siberian Federal University. Chemistry 2013. V. 6(4). P. 380-393 (in Russ.)]

15. Alvin B. Stiles Catalyst Supports and Supported Catalysts: Theoretical and Applied Concepts. Butterworth Publishers, Stoneham, MA.1987. 270 p.

16. Веприкова Е.В., Кузнецов Б.Н., Чесноков Н.В. Получение биокомпозитных фосфоркалийных удобрений пролонгированного действия на основе коры лиственницы. Химия растительного сырья 2017. №3. С. 201-209. [Veprikova E.V., Kuznetsov B.N., Chtsnokov N.V. Preparation of biocomposite phosphorus-potassium fertilizers with long-time action on the base of a larch bark. Chemistry of plant raw materials 2017. №3. P. 201-209. (in Russ.)]

17. Вульфсон Н.С. Препаративная органическая химия, пер. с нем. М.: ГХИ, 1959. 889 с. [Wolfson N.C. Preparation organic chemistry, Transl. from German. M.: GCh.I. 1959. 889 p. (in Russ.)]

18. Патент 2468074 RU. Бовт B.В., Миков А.И. Композиция на основе нитрата карбамида с повышенной растворимостью и способ повышения растворимости нитрата карбамида. Опубл. 27.11.2012. [Patent 2468074 RU. Bovt V.V., Mikov A.I. Composition on the base of carbamide nitrate with increased solubility and method of solubility increase of carbamide nitrate. Publ. Date 27.11.2012 (in.Russ.)] 
19. Infrared and Raman characteristic group frequencies: Tables and charts. G. Socrates. John Wiley-Sons, 2004. 347 p.

20. Сергеев Ю.А., Кузнецов Н.М., Чирков А.В. Карбамид: Свойства, производство, применение: монография. Нижний Новгород: Кварц, 2015. 543 с. [Sergeev Yu.A., Kuznetsov N.M., Chirkov A.V. Carbamide: Properties, production, application: monograph. Nizhny Novgorod: Karts, 2015. 543 p. (in Russ.)] 